\title{
Microbiological Quality of Raw Goat's and Ewe's Bulk-Tank Milk in Switzerland
}

\author{
J. E. Muehlherr*, C. Zweifel*, S. Corti*, J. E. Blanco,† and R. Stephan* \\ ${ }^{*}$ Institute for Food Safety and Hygiene, Faculty of Veterinary Medicine, University of Zurich, \\ $\mathrm{CH}-8057$ Zurich, Switzerland \\ †Laboratorio de Referencia de E. coli (LREC), Departamento de Microbioloxía e Parasitoloxía, \\ Facultade de Veterinaria, Universidade de Santiago de Compostela, 27002 Lugo, Spain
}

\begin{abstract}
A total of 407 samples of bulk-tank milk (344 of goat's milk and 63 of ewe's milk) collected from 403 different farms throughout Switzerland, was examined. The number of farms investigated in this study represents $8 \%$ of the country's dairy-goat and $15 \%$ of its dairysheep farms. Standard plate counts and Enterobacteriaceae counts were performed on each sample. Furthermore, the prevalence of Staphylococcus aureus, Campylobacter spp., Shiga toxin-producing Escherichia coli, Salmonella spp., and Mycobacterium avium ssp. paratuberculosis was studied. The median standard plate count for bulk-tank milk from small ruminants was $4.70 \mathrm{log} \mathrm{cfu} / \mathrm{ml}$ (4.69 log cfu/ml for goat's milk and 4.78 $\log \mathrm{cfu} / \mathrm{ml}$ for ewe's milk), with a minimum of $2.00 \mathrm{log}$ $\mathrm{cfu} / \mathrm{ml}$ and a maximum of $8.64 \mathrm{log} \mathrm{cfu} / \mathrm{ml}$. Enterobacteriaceae were detected in $212(61.6 \%)$ goat's milk and 45 (71.4\%) ewe's milk samples, whereas $S$. aureus was detected in 109 (31.7\%) samples of goat's milk and 21 (33.3\%) samples of ewe's milk.

Campylobacter spp. and Salmonella spp. were not isolated from any of the samples. However, $16.3 \%$ of the goat's milk and $12.7 \%$ of the ewe's milk samples were polymerase chain reaction (PCR)-positive for Shiga toxin-producing E. coli. Seventy-nine (23.0\%) goat's tank-milk and 15 (23.8\%) ewe's tank-milk samples were PCR-positive for insertion sequence 900, providing presumptive evidence for the presence of $M$. avium ssp. paratuberculosis. These results form the basis for determining the microbiological quality standards for goat's and ewe's milk. Moreover, the data presented form part of the risk assessment program for raw milk from small ruminants in Switzerland.
\end{abstract}

(Key words: food-borne pathogen, goat's and ewe's milk, microbiological quality, prevalence)

Received March 12, 2003.

Accepted June 5, 2003.

Corresponding author: R. Stephan; e-mail stephanr@fsafety. unizh.ch.
Abbreviation key: $\mathbf{C I}=$ confidence interval, $\mathbf{I S}=$ insertion sequence, $\mathbf{M A P}=$ Mycobacterium avium ssp. paratuberculosis, $\mathbf{S P C}=$ standard plate count, $\mathbf{S T E C}=$ Shiga toxin-producing Escherichia coli, D-value = decimal reduction time.

\section{INTRODUCTION}

Public health problems associated with consumption of unpasteurized cow's milk and raw-milk products have been well documented (Barrett, 1986; Keene et al., 1997; Cody et al., 1999; De Valk et al., 2000; Kalman et al., 2000; De Buyser et al., 2001; Harrington et al., 2002). There is no evidence that the risk from unpasteurized goat's or ewe's milk is any lower (Hutchinson et al., 1985; Allerberger et al., 2001; McIntyre et al., 2002). Pathogenic microorganisms can gain access to milk either by fecal contamination or by direct excretion from the udder into the milk.

Unlike cow's milk, which is subject to stringent hygiene and quality regulations, microbiological standards for production and distribution of goat's and ewe's milk are more relaxed in Switzerland and are not subject to specific microbiological standards in a legal sense. Furthermore, the literature provides only limited data on the microbiology of goat's and ewe's milk in other countries (Roberts, 1985; Little and Louvois, 1999; Foschino et al., 2002) and none at all for Switzerland.

Nevertheless, there is growing demand for unpasteurized goat's and ewe's milk by consumers in Switzerland. This is due to the increasing number of children suffering from intolerance to cow's milk as well as to the demand for natural and unprocessed food. Furthermore, traditional Swiss goat's and sheep's cheese is typically made from raw milk with the natural microflora responsible for enhancing desirable flavor characteristics of the final product. So there is a clear need to find out more about the present situation regarding the quality of goat's and ewe's milk in Switzerland.

The objectives of this study were to 1) determine the microbiological status of goat's and ewe's milk in Swit- 


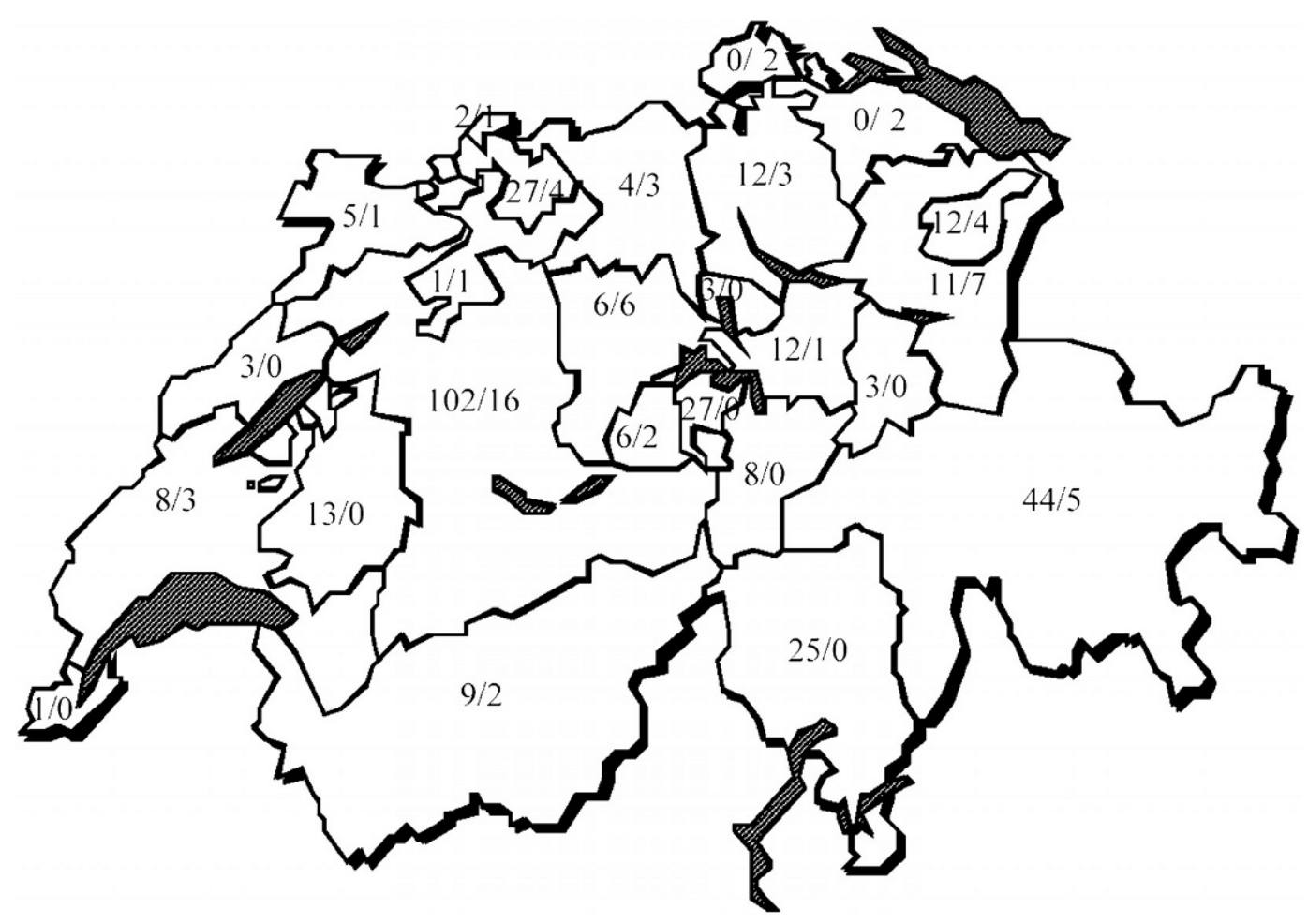

Figure 1. Sampling of small ruminant's milk throughout 25 of Switzerland's 26 cantons (goat's bulk-tank milks/ewe's bulk-tank milks).

zerland and 2) study the prevalence of food-borne pathogens, especially Staphylococcus aureus, Campylobacter spp., Shiga toxin-producing Escherichia coli (STEC), Salmonella spp. and Mycobacterium avium ssp. paratuberculosis (MAP).

\section{MATERIALS AND METHODS}

\section{Milk Samples}

Between February and August 2002, a total of 407 bulk-tank milk samples (344 goat's milk and 63 ewe's milk) were collected from 403 farms with a total of approximately 11,000 animals (8000 goats and 3000 ewes). The number of farms investigated represents $8 \%$ of Switzerland's dairy-goat and 15\% of its dairy-sheep farms. Goat farms ranged in size from two to 180 animals and ewe farms from 2 to 300 animals. The farms were distributed throughout 25 of Switzerland's 26 cantons (Figure 1 ) and were categorized in three groups $(<6$ animals, 6 to 25 animals, $>25$ animals). The numbers of farms investigated in these groups were selected according to the frequency of distribution of the various farm sizes in Switzerland.

Sampling was performed after cooling the milk aseptically either at the farm itself or from various milkcollection points. After purchase, the samples were placed directly into cool boxes and transported to the laboratory. The samples were processed within 24 to $48 \mathrm{~h}$. For the detection of MAP, $20 \mathrm{ml}$ of milk was stored at $-20^{\circ} \mathrm{C}$ before being investigated.

\section{Standard Plate Count and Enterobacteriaceae Count}

Standard plate count (SPC) and Enterobacteriaceae counts were determined by pour plate method with plate count agar (Oxoid, Basingstoke, U.K.) and violetred bile glucose agar (BBL, Cockeysville, MD), respectively. The detection limit was at $1.0 \times 10^{0} \mathrm{cfu} / \mathrm{ml}$.

\section{Staphylococcus aureus}

Numbers of $S$. aureus were determined by surfaceplating the samples on rabbit-plasma-fibrinogen agar (Oxoid CM 275 with RPF supplement Sedia 2000-0100). The detection limit was $1.0 \times 10^{1} \mathrm{cfu} / \mathrm{ml}$. The number of coagulase-positive staphylococci was obtained by direct enumeration of typical colonies (tellurite-positive colonies with an opaque halo).

\section{Campylobacter spp.}

Ten milliliters of milk was inoculated into $100 \mathrm{ml}$ of selective enrichment broth (Brucella Bouillon [Difco 
0495-17-3, Becton Dickinson, Sparks, MD] with Campylobacter growth supplement [Oxoid SR84] and Skirrow Campylobacter selective supplement [Oxoid SR69]) and incubated at $42^{\circ} \mathrm{C}$ for $48 \mathrm{~h}$ under microaerobic conditions provided by commercial gas packs (CampyGen from Oxoid). The enrichment samples were then streaked onto selective agar media (Brucella agar, [Difco 0964-17-5, Becton Dickinson] with 6\% horse blood [Oxoid SR48], as well as Butzler Campylobacter selective supplement [Oxoid SR85]) and incubated at $42^{\circ} \mathrm{C}$ for another $48 \mathrm{~h}$ under microaerobic conditions. Suspicious colonies, appearing translucent white, moist, and glistening, were selected for further identification.

\section{Shiga Toxin-Producing E. coli}

From each sample, $25 \mathrm{ml}$ was enriched in $225 \mathrm{ml}$ of brilliant-green bile broth (BBL) at $37^{\circ} \mathrm{C}$ for $24 \mathrm{~h}$. The enrichment broth was then evaluated by PCR with primers based on sequences targeting a region between stx 1 and stx 2 genes (Burnens et al., 1995). Bacterial DNA was prepared by incubating $2 \mu \mathrm{l}$ of brilliant-green bile broth in $42 \mu \mathrm{l}$ of double-distilled water at $100^{\circ} \mathrm{C}$ for $10 \mathrm{~min}$. Amplifications were carried out with a total volume of $50 \mu \mathrm{l}$ containing $200 \mu M$ of dNTP, $30 \mathrm{pmol}$ of each primer, $5 \mu \mathrm{l}$ of 10 -fold concentrated polymerase synthesis buffer, and $2.5 \mathrm{U}$ of Taq-DNA-polymerase (Promega, Madison, WI) in a Biometra DNA cycler. The amplified products were visualized by gel electrophoresis on $0.9 \%$ agarose gel stained with ethidium bromide.

From 40 PCR-positive samples, the enrichment broth was plated onto sheep blood agar (Trypticase-Soy-Agar, BBL with $5 \%$ sheep blood), and five single colonies were tested by the same PCR protocol to obtain STEC isolates. The strains were identified with classic biochemical tests (acid production from mannitol, $o$-nitrophenyl$\beta$-D-galactopyranoside test, $\mathrm{H}_{2} \mathrm{~S}$ and indole production, as well as proof of urease and lysine decarboxylase). All strains were examined for sorbitol fermentation, for $\beta$-D-glucuronidase activity, and for the presence of stx 1 and stx2 genes (Blanco et al., 2003). The PCR-RFLP was used for subtyping stx2 variants (Piérard et al., 1998). Furthermore, PCR was employed to determine the presence of the eae, hlyA, and ast $\mathrm{A}$ genes (Schmidt et al., 1994; 1995; Yamamoto and Nakazawa, 1997).

The determination of $\mathrm{O}$ and $\mathrm{H}$ antigens was carried out by the method described by Guinée et al. (1981), employing all available $\mathrm{O}(\mathrm{O} 1-\mathrm{O} 181)$ and $\mathrm{H}$ (H1-H56) antisera.

\section{Salmonella spp.}

Salmonella spp. were detected in a two-stage enrichment procedure. Twenty-five $\mathrm{ml}$ of milk was pre-en- riched in $225 \mathrm{ml}$ of buffered peptone water (Oxoid CM 509) at $37^{\circ} \mathrm{C}$ for $24 \mathrm{~h}$. Ten milliliters of the pre-enrichment sample was then incubated in $100 \mathrm{ml}$ of tetrathionate (Oxoid CM 343) or $0.1 \mathrm{ml}$ of the pre-enriched sample in $10 \mathrm{ml}$ of Rappaport-Vassiliadis medium (Oxoid CM 669) at $37^{\circ} \mathrm{C}$ or $43^{\circ} \mathrm{C}$ for another $24 \mathrm{~h}$. Enrichments were then streaked onto brilliant-green phenol red agar (Difco 0285-17-7, Becton Dickinson) and mannitol-lysin crystal-violet brilliant green agar (Brandenberger, Zurich, Switzerland). Both selective media were incubated at $37^{\circ} \mathrm{C}$ for $24 \mathrm{~h}$.

\section{Mycobacterium avium ssp. paratuberculosis}

Ten milliliters of each sample was mixed with 100 $\mu \mathrm{l}$ of Triton X-100 (Calbiochem, Darmstadt, Germany) and centrifuged at $4500 \mathrm{rpm}$ for $30 \mathrm{~min}$. Afterwards, the pellet was transferred to a Blue Ribolyser tube (Hybaid, Ashford, U.K.), resuspended in $400 \mu$ l of mycobacterial lysis buffer (EDTA, 2mM; sodium chloride, $400 \mathrm{mM}$, TrisHCl, $10 \mathrm{mM}$ (pH 8.0); 0.6\% SDS; proteinase K, 33 $\mu \mathrm{l} / \mathrm{ml}$ ) and incubated overnight at $37^{\circ} \mathrm{C}$. For access to target DNA, samples were centrifuged at $6.5 \mathrm{~m} / \mathrm{s}$ for 45 $\mathrm{s}$ in a RiboLyser (Hybaid). The DNA was then extracted with 1 volume of phenol/chloroform/isoamyl-alcohol (25:24:1) and precipitated with $3 M$ potassium acetate for $30 \mathrm{~min}$ at $-70^{\circ} \mathrm{C}$, centrifuged $(13,000 \mathrm{rpm}, 15 \mathrm{~min})$, washed in $70 \%$ ethanol, dried, and resuspended in TEbuffer (10 mM Tris, $1 \mathrm{~m} M$ EDTA, $\mathrm{pH}$ 8.0).

Five microliters of the resuspended DNA was used for an insertion sequence (IS) 900-nested PCR specific to MAP. According to Hermon-Taylor et al. (2000), the primers p90 5'-GAA GGG TGT TCG GGG CCG TCG CTT AGG-3' and p91 5'-GGC GTT GAG GTC GAT CGC CCA CGT GAC-3' were used for the first 30 amplification cycles. The PCR mix consisted of $50 \mu \mathrm{l}$ of reaction volume containing a final concentration of $2 \mu M$ of each primer, $2.5 \mathrm{~m} M \mathrm{MgCl}_{2}, 100 \mu M \mathrm{dNTP}$, and $2 \mathrm{U}$ Taq polymerase (Promega) in $1 \times$ reaction buffer (Promega). The reactions were cycled as follows: initial denaturation at $94^{\circ} \mathrm{C}$ for $5 \mathrm{~min} ; 30$ cycles of $94^{\circ} \mathrm{C}$ for $1 \mathrm{~min}$, $58^{\circ} \mathrm{C}$ for $1 \mathrm{~min}$, and $72^{\circ} \mathrm{C}$ for $3 \mathrm{~min}$; and a final extension of $72^{\circ} \mathrm{C}$ for $7 \mathrm{~min}$.

Two microliters from the primary amplification were then used with the primers AV1 5'-ATG TGG TTG CTG TGT TGG ATG G-3' and AV2 5'-CCG CCG CAA TCA ACT CCA G-3' for the nested PCR. The PCR mix consisted of a $50-\mu \mathrm{l}$ reaction volume containing a final concentration of $2 \mu M$ of each primer, $1.5 \mathrm{mM} \mathrm{MgCl} 2,100$ $\mu M \mathrm{dNTP}$, and $2 \mathrm{U}$ Taq polymerase (Promega) in $1 \times$ reaction buffer (Promega). The reactions were cycled as follows: initial denaturation at $94^{\circ} \mathrm{C}$ for $5 \mathrm{~min} ; 40$ cycles of $94^{\circ} \mathrm{C}$ for $1 \mathrm{~min}, 58^{\circ} \mathrm{C}$ for $1 \mathrm{~min}$, and $72^{\circ} \mathrm{C}$ for $3 \mathrm{~min}$; and a final extension of $72^{\circ} \mathrm{C}$ for $7 \mathrm{~min}$. The PCR 
Table 1. Selected statistical values of standard plate count (SPC) and Enterobacteriaceae counts (goat's milk $\mathrm{n}=344$, ewe's milk $\mathrm{n}=63$ ).

\begin{tabular}{lrrrrr}
\hline & \multicolumn{2}{c}{ SPC $(\mathrm{log} \mathrm{cfu} / \mathrm{ml})$} & & \multicolumn{2}{c}{ Enterobacteriacea $(\mathrm{log} \mathrm{cfu} / \mathrm{ml})^{1}$} \\
\cline { 2 - 3 } & Goat's milk & Ewe's milk & & Goat's milk & Ewe's milk \\
\hline Median & 4.69 & 4.78 & & 1.88 & 2.08 \\
50\% range & $3.92-5.92$ & $3.69-5.31$ & & $\varnothing-3.20$ & $\varnothing-3.56$ \\
90\% range & $3.25-6.90$ & $2.89-6.16$ & & $\varnothing-4.66$ & $\varnothing-4.29$ \\
Mean & 6.92 & 5.93 & & 5.72 & 3.93 \\
Standard deviation & 7.63 & 6.44 & & 6.51 & 3.48 \\
Standard error & 6.36 & 5.54 & & 5.25 & \\
Confidence interval (95\%) & $6.58-71$ & $5.16-6.19$ & & $5.26-5.94$ & $2.97-4.20$ \\
Minimum & 2.00 & 2.30 & & $\varnothing$ & $\varnothing$ \\
Maximum & 8.64 & 7.26 & & 7.64 & 5.34 \\
\hline
\end{tabular}

${ }^{1} \varnothing=$ below detection limit $\left(1.0 \times 10^{0} \mathrm{cfu} / \mathrm{ml}\right)$.

products were visualized on $1.5 \%$ agrose gels (Eurobio, Les Ulis Cedex, France). The IS900-nested product is $298 \mathrm{bp}$ in length.

\section{Statistical Analysis}

The statistical significance was determined by the $\chi^{2}$-test $(P<0.05)$, the Mann-Whitney U-test $(P<0.05)$ and the Kruskal Wallis H-test $(P<0.05)$.

\section{RESULTS}

The median SPC for bulk-tank milk from small ruminants was $4.70 \mathrm{log} \mathrm{cfu} / \mathrm{ml}$, with a minimum of $2.00 \mathrm{log}$ $\mathrm{cfu} / \mathrm{ml}$ and a maximum of $8.64 \mathrm{log} \mathrm{cfu} / \mathrm{ml}$. Median SPC was $4.69 \log \mathrm{cfu} / \mathrm{ml}$ for goat's milk and $4.78 \mathrm{log} \mathrm{cfu} / \mathrm{ml}$ for ewe's milk. Enterobacteriaceae were detected in 212 (61.6\%; confidence interval [CI] of $95 \%=61.01$ to 71.96) goat's milk and $45(71.4 \%$, CI $95 \%=56.98$ to 80.77$)$ ewe's milk samples. The median value was $1.88 \mathrm{log} \mathrm{cfu} /$ $\mathrm{ml}$ for goat's milk, with a maximum of $7.64 \mathrm{log} \mathrm{cfu} / \mathrm{ml}$, and $2.08 \mathrm{log} \mathrm{cfu} / \mathrm{ml}$ for ewe's milk, with a maximum of $5.34 \mathrm{log} \mathrm{cfu} / \mathrm{ml}$. Selected statistical values of SPC and Enterobacteriaceae counts are summarized in Table 1. The frequency distributions of SPC and Enterobacteriaceae counts for goat's and ewe's milk are shown in Figure 2.

An increase in the median SPC and Enterobacteriaceae, counts depending on milk delivery frequency and different farm sizes ( $<6$ animals, 6 to 25 animals, $>25$ animals), is shown in Table 2. Among farms with daily milk deliveries and farms with deliveries every second or third day, significant differences in SPC results were found $(P<0.05)$. Moreover, the statistical analysis showed significant differences for SPC and Enterobacteriaceae counts between the described categories of farm sizes $(P<0.05)$.

Staphylococcus aureus was detected in 109 (31.7\%, CI $95 \%=31.22$ to 42.40$)$ goat's milk and $21(33.3 \%$, CI
$95 \%=21.95$ to 46.34 ) ewe's milk samples. The median value for goat's and ewe's-milk samples was $<1 \log \mathrm{cfu} /$ $\mathrm{ml}$, with a maximum of $4.34 \mathrm{log} \mathrm{cfu} / \mathrm{ml}$ for goat's and $3.56 \mathrm{log} \mathrm{cfu} / \mathrm{ml}$ for ewe's milk.

The prevalence of Campylobacter spp., STEC, Salmonella spp., and MAP are shown in Table 3. Campylobacter spp. and Salmonella spp. were not isolated from any of the samples. However, STEC PCR was positive in $62(15.2 \%)$ of the 407 milk samples examined. Also, $16.3 \%$ (CI $95 \%=15.63$ to 24.99 ) of goat's milk samples and $12.7 \%$ (CI 95\% = 5.65 to 23.50) of ewe's milk samples were stx positive. Twelve STEC strains were isolated and further characterized (Table 4). All the strains belonged to the non-O157 E. coli group and tested positive for sorbitol and $\beta$-D-glucuronidase. One strain harbored only the stx 1 gene, one strain only the stx 2 gene, and 10 strains the stx 1 and stx 2 genes. Nine strains tested positive for EHEC-hlyA, one strain tested positive for the eae gene, and no strain harbored the ast $\mathrm{A}$ gene.

Seventy-nine $(23.0 \%$, CI 95\% $=21.76$ to 32.06$)$ goat's milk and $15(23.8 \%$, CI 95\% = 13.98 to 36.21$)$ ewe's milk samples were IS900 PCR positive. The prevalence of milk samples containing IS900 in different geographical regions of Switzerland ranged from 17 to $34 \%$. Seventeen percent of the bulk-tank milk samples from the north-east, $26 \%$ of the samples from the center, $21 \%$ of the samples from the north-west, and $34 \%$ of the bulktank milk samples from the southern part of Switzerland tested IS900 PCR-positive.

\section{DISCUSSION}

No significant differences could be detected in SPC and Enterobacteriaceae counts as a function of the animal species (sheep/goats). Therefore, the same microbiological limit value can be used to assess the quality of both sheep's and goat's milk. According to European Council Directive 92/46/EEC, raw goat's or sheep's milk used to produce drinking milk and products from heat- 
SPC goat's milk, $n=344$

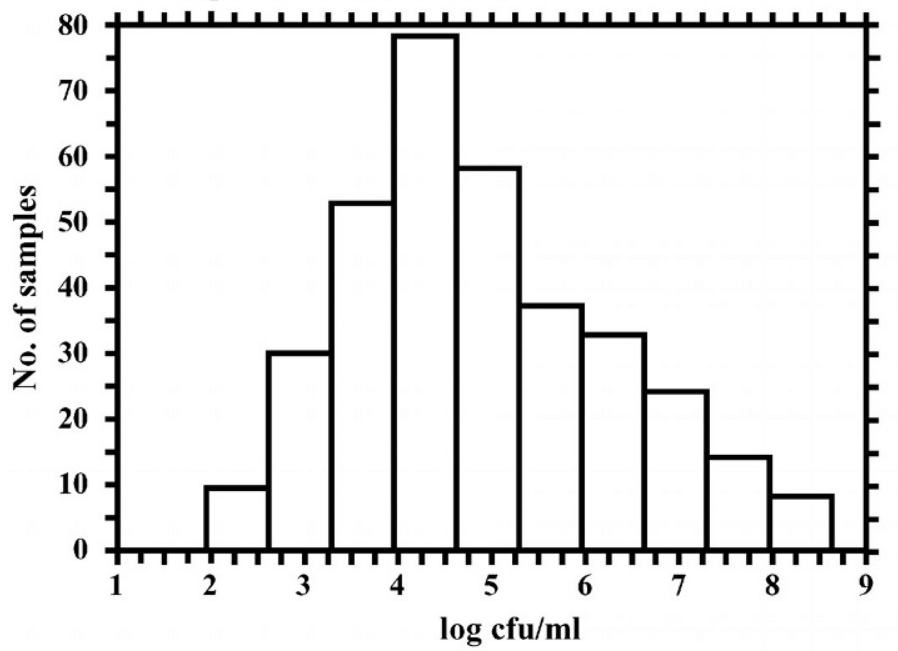

SPC ewe's milk, $n=63$

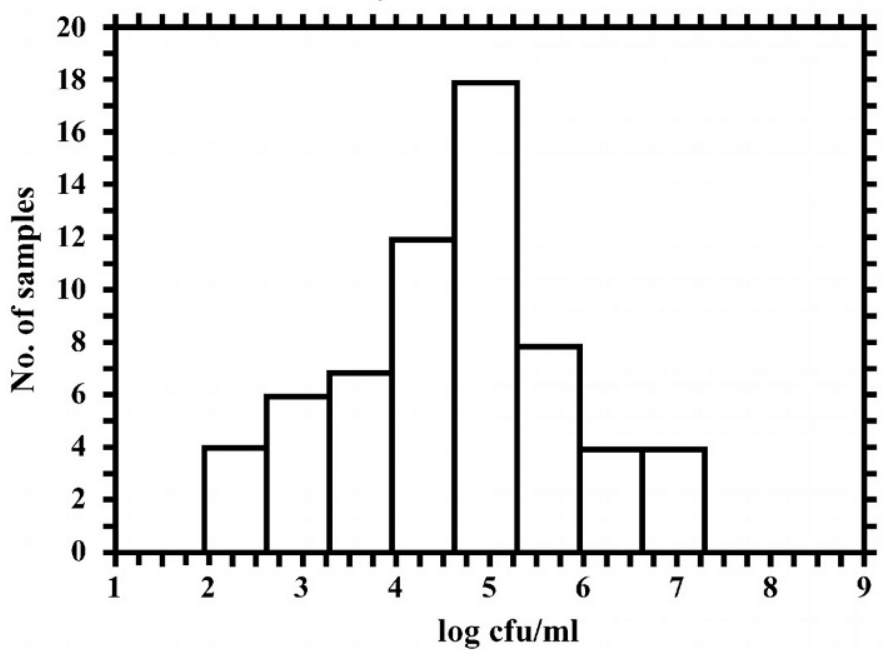

Enterobacteriaceae counts goat's milk, $\mathrm{n}=\mathbf{2 1 2}$

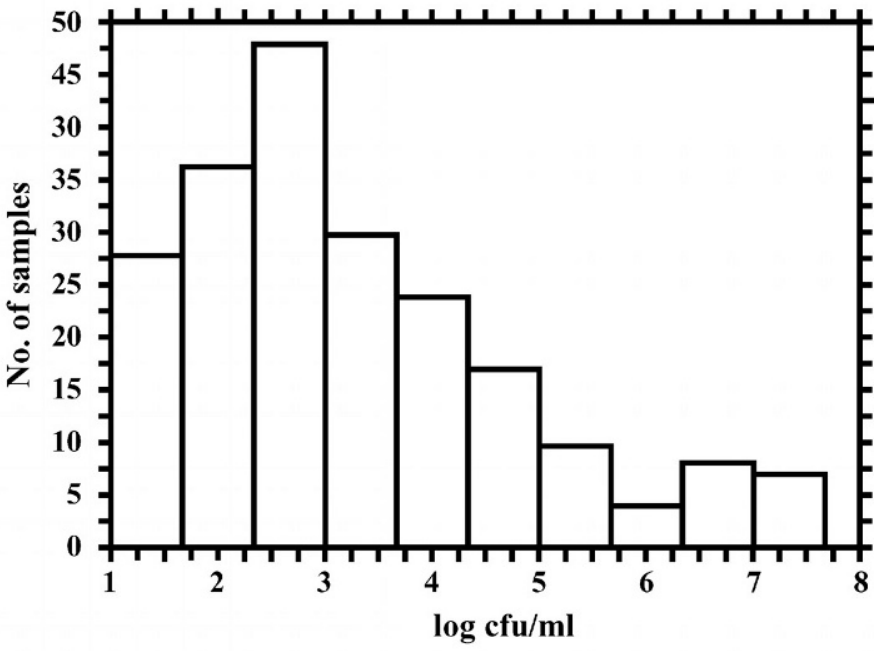

Enterobacteriaceae counts ewe's milk, $n=45$

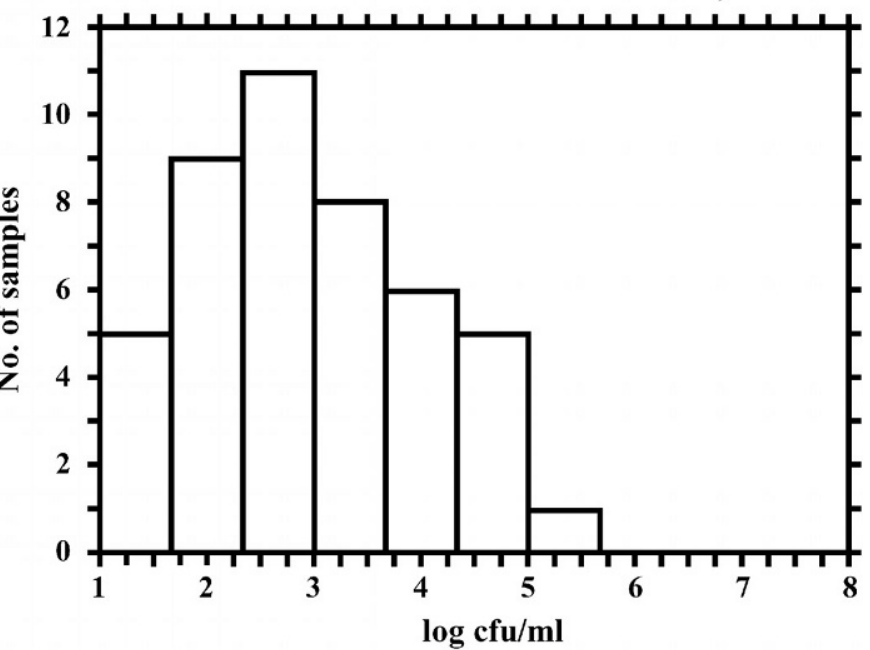

Figure 2. Frequency distributions of SPC and Enterobacteriaceae counts for goat's and ewe's bulk-tank milk.

Table 2. Median values (log cfu/ml) of standard plate count (SPC) and Enterobacteriaceae counts depending on frequency of milk delivery and farm sizes.

\begin{tabular}{|c|c|c|c|c|}
\hline & \multicolumn{2}{|c|}{ SPC } & \multicolumn{2}{|c|}{ Enterobacteriaceae } \\
\hline & Goat's milk & Ewe's milk & Goat's milk & Ewe's milk \\
\hline $\begin{array}{l}\text { Median } \\
\text { Frequency of milk delivery }{ }^{1}\end{array}$ & $4.69(\mathrm{n}=344)$ & $4.78(\mathrm{n}=63)$ & $1.88(\mathrm{n}=344)$ & $2.08(\mathrm{n}=63)$ \\
\hline Daily & $4.32(\mathrm{n}=197)$ & $4.61(\mathrm{n}=43)$ & $1.00(\mathrm{n}=197)$ & $2.00(\mathrm{n}=43)$ \\
\hline $\begin{array}{l}\text { Every second or third day } \\
\text { Farm size }^{2}\end{array}$ & $5.68(\mathrm{n}=135)$ & $4.88(\mathrm{n}=20)$ & $2.61(\mathrm{n}=135)$ & $2.69(\mathrm{n}=20)$ \\
\hline $\begin{array}{l}<6 \text { animals } \\
6 \text { to } 25 \text { animals } \\
>25 \text { animals }\end{array}$ & $\begin{array}{l}4.43(\mathrm{n}=58) \\
4.66(\mathrm{n}=167) \\
4.97(\mathrm{n}=86)\end{array}$ & $\begin{array}{l}3.66(\mathrm{n}=7) \\
4.49(\mathrm{n}=17) \\
4.75(\mathrm{n}=34)\end{array}$ & $\begin{array}{l}1.30(\mathrm{n}=58) \\
1.48(\mathrm{n}=167) \\
2.45(\mathrm{n}=86)\end{array}$ & $\begin{array}{l}1.30(\mathrm{n}=7) \\
1.70(\mathrm{n}=17) \\
2.56(\mathrm{n}=34)\end{array}$ \\
\hline
\end{tabular}

${ }^{1}$ No. of evaluated farms: 395 , from 12 farms, no data were available.

${ }^{2}$ No. of evaluated farms: 369 , from 38 farms, no data were available. 
Table 3. Prevalence of Campylobacter spp., salmonella spp., Shiga toxin-producing Escherichia coli (STEC) and Mycobacterium avium subsp. paratuberculosis (MAP) for 344 goat's and 63 ewe's milk samples.

\begin{tabular}{lcr}
\hline & \multicolumn{2}{c}{ No. (\%) of positive samples } \\
\cline { 2 - 3 } Pathogen & Goat's milk & Ewe's milk \\
\hline Campylobacter spp. & $0(0 \%)$ & $0(0 \%)$ \\
Salmonella spp. & $0(0 \%)$ & $0(0 \%)$ \\
STEC & $55(16 \%)$ & $8(13 \%)$ \\
MAP & $79(23 \%)$ & $15(24 \%)$ \\
\hline
\end{tabular}

treated milk must not contain more than $6.00 \log \mathrm{cfu} /$ $\mathrm{ml}$ (SPC), and the milk used for the manufacture of raw-milk products not more than $5.70 \mathrm{log} \mathrm{cfu} / \mathrm{ml}$ (SPC). In our study, $77 \%$ of the goat's milk and $86 \%$ of the sheep's milk or $73 \%$ of the goat's and $81 \%$ of the sheep's milk SPC results, respectively, were below the SPC limits fixed by the EU regulations. The microbiological quality standard stipulated by European Council Directive 92/46/EEC may therefore be used as a basis for developing a specific quality standard system for milk from small ruminants in Switzerland.

The delivery frequency of the milk supplied had an impact on the SPC of the milk samples. The observed significant differences in SPC between farms with daily milk deliveries and those with deliveries every second or third day suggested some difficulty in cooling the milk on farm for a longer period. The increase in microbial contamination of milk samples obtained from farms with more animals was quite unexpected. We assumed that farms with more animals would have more professional hygiene management, resulting in lower microbial counts.

The SPC median values of goat's and ewe's milk were one log unit higher than the median value of cow's tank milk (Stephan and Bühler, 2001). In addition, striking differences were found in the prevalence of the Enterobacteriaceae: $7 \%$ for cow's milk samples compared with $62 \%$ for goat's milk and $70 \%$ for sheep's milk samples. These results suggest some difficulty in managing the hygiene quality of small ruminant's milk, which may be due to a series of factors including the milking system. In contrast, the prevalence of $S$. aureus in milk samples from small ruminants $(32 \%)$ is only half as frequent as that found in cow's milk samples (Stephan et al., 2002).

Other surveys of pathogen prevalence in goat's and ewe's milk provided results comparable to those of our study, showing no Salmonella or Campylobacter-positive samples (Little et al., 1999; Foschino et al., 2002; Morgan et al., 2003). However, $16.3 \%$ of the goat's milk and $12.7 \%$ of the ewe's milk samples were positive for STEC. The importance of the STEC group has increased since the first description of a food-borne infection caused by E. coli O157:H7 (Riley et al., 1983). Human STEC infection after raw milk consumption was first mentioned by Martin et al. (1986) and has now gained greater importance, in particular due to the very low minimum infectious dose. The risk associated with consumption of unpasteurized goat's milk is documented in the literature (Bielaszewska et al., 1997; McIntyre et al., 2002). Frequently, STEC strains isolated from patients are of serotype $\mathrm{O} 157$ and show a typical virulence spectrum, with such strains tending to be $s t x 2$ and eae-positive (Boerlin et al., 1999). The stx2d variant was the principal stx2 subtype in strains isolated from small ruminants in our study, and has so far not been detected in STEC strains isolated from patients. Only one STEC strain with serotype ONT:H19 harbored stx2 and eae genes. Despite the low prevalence of strains with the typical virulence pattern in bulk-tank samples,

Table 4. Characterization results of 12 Shiga toxin-producing Escherichia coli strains isolated from raw bulk-tank milk samples from small ruminants.

\begin{tabular}{|c|c|c|c|c|c|c|}
\hline \multirow[b]{2}{*}{ Origin } & \multirow[b]{2}{*}{ Serotype } & \multicolumn{5}{|c|}{ Virulence factors } \\
\hline & & stx 1 & $s t x 2$ & EHEC-hly & eae & $\operatorname{ast} \mathrm{A}$ \\
\hline Goat milk & $\mathrm{O} 5: \mathrm{H}-1$ & + & stx $2 c$ & + & - & - \\
\hline Goat milk & $\mathrm{O} 5: \mathrm{H}-{ }^{1}$ & + & stx2c & + & - & - \\
\hline Goat milk & $\mathrm{O} 76: \mathrm{H}_{1} 9^{2}$ & + & - & + & - & - \\
\hline Ewe milk & O87:H16 & - & stx $2 d$ & - & - & - \\
\hline Ewe milk & O87:H16 & - & stx $2 d$ & - & - & - \\
\hline Goat milk & O91:H?² & + & stx $2 d$ & + & - & - \\
\hline Goat milk & $\mathrm{O} 113: \mathrm{H} 4^{2}$ & + & stx2d & + & - & - \\
\hline Goat milk & $\mathrm{O} 113: \mathrm{H} 4^{2}$ & + & stx2d & + & - & - \\
\hline Goat milk & $\mathrm{O} 113: \mathrm{H} 4^{2}$ & + & stx2d & + & - & - \\
\hline Goat milk & $\mathrm{O} 113: \mathrm{H} 4^{2}$ & + & stx $2 d$ & + & - & - \\
\hline Goat milk & $\mathrm{O} 174(\mathrm{OX} 3): \mathrm{H} 8^{2}$ & + & stx2d & - & - & - \\
\hline Ewe milk & ONT:H19 ${ }^{1}$ & - & stx2 & + & + & - \\
\hline
\end{tabular}

${ }^{1}$ Serotypes previously associated with human STEC strains that caused HUS.

${ }^{2}$ Serotypes previously found in human STEC strains. 
infections due to consumption of raw milk can not be excluded. However, pasteurization of milk $\left(71.7^{\circ} \mathrm{C}\right.$ for $15 \mathrm{~s}$, Swiss food regulation) offers sufficient protection.

MAP is a pathogen that causes chronic, granulomatous inflammation of the intestine in various animals, including cattle and small ruminants, and can also be cultured from milk of apparently healthy animals (Streeter et al., 1995). Today, it seems increasingly probable that MAP could play a role in the etiology of Crohn's disease (Hermon-Taylor et al., 2000). However, conclusive evidence for the etiological role of MAP in Crohn's disease is still lacking.

Raw milk may be a potential vehicle for transmission of MAP to humans. Therefore, MAP has acquired special relevance to food hygiene. Moreover, results of laboratory pasteurization tests of raw whole milk spiked with MAP showed that MAP was capable of surviving pasteurization (Chiodini and Hermon-Taylor, 1993; Grant et al., 1998; Keswani and Frank, 1998; Sung and Collins, 1998). Nevertheless, conflicting results can be found in the literature. Sung and Collins (1998) reported a decimal reduction time (D-value) for MAP in milk of $11 \mathrm{~s}$ at $71^{\circ} \mathrm{C}$, indicating that MAP could survive HTST pasteurization if the initial numbers were $>1 \mathrm{log}$ $\mathrm{cfu} / \mathrm{ml}$ milk. Pearce et al. (2001), however, reported a $\mathrm{D}$-value of $2.03 \mathrm{~s}$ at $72^{\circ} \mathrm{C}$, which is equivalent to a $>7$ $\log$ reduction at $72^{\circ} \mathrm{C}$ for $15 \mathrm{~s}$ (HTST pasteurization). Grant et al. (2002) pasteurized raw cows' milk naturally infected with MAP and found that MAP survived commercial-scale pasteurization at $73^{\circ} \mathrm{C}$ for $15 \mathrm{~s}$ and $25 \mathrm{~s}$ with and without prior homogenization if the bacterial cells were present in sufficient numbers before heat treatment.

The $23 \%$ prevalence in goat's and $24 \%$ in ewe's milk IS900 PCR-positive bulk-milk samples indicates a wide distribution of subclinical MAP infections in small dairy ruminants in Switzerland. Polymerase chain reaction targeting the $5^{\prime}$ end of IS900 has been considered specific for identification of MAP and is frequently applied to confirm the presence of this organism. However, the finding of an insertion sequence very similar to IS900 in a Mycobacterium sp. unrelated to MAP has raised questions concerning the reliability of PCR methods for detection of MAP (Cousins et al., 1999; Englund et al., 2002).

No other comparative data on the occurrence of MAP in goat's and ewe's milk are currently available for Switzerland. Djonne et al. (2003) examined raw goat's milk in Norway. In their study, $7.1 \%$ of the samples tested positive by an immunomagnetic separation PCR method. In a survey by Grant et al. (2001) in England, one raw goat-milk sample from 104 raw sheep's and goat's milk samples tested positive for the presence of MAP by immunomagnetic separation PCR.
In a previous study, we demonstrated that $19.7 \%$ of raw bulk-tank milk samples obtained from cows in Switzerland were IS900 positive (Corti and Stephan, 2002). Compared with cow's milk, no statistically significant regional differences in MAP herd-level prevalence were found for small ruminants.

The results of this study could form the basis for determining specific microbiological quality standards for goat's and ewe's milk in Switzerland. Moreover, they constitute part of the Swiss risk assessment program for raw milk from small ruminants.

\section{ACKNOWLEDGMENT}

The authors would like to thank F. Del Chicca and S. Schumacher for their technical assistance. This study was partly supported by a grant from the Fondo de Investigación Sanitaria (FIS G03/025-COLIRED157).

\section{REFERENCES}

Allerberger, F., M. Wagner, P. Schweiger, H. P. Rammer, A. Resch, M. P. Dierich, A.W. Friedrich, and H. Karch. 2001. Escherichia coli O157 infections and unpasteurised milk. Euro Surveill. $6: 147-151$.

Barrett, N. J. 1986. Communicable disease associated with milk and dairy products in England and Wales: 1983-1984. J. Infect. 12:265-272.

Bielaszewska, M., J. Janda, K. Blahova, H. Minarikova, E. Jikova, M. A. Karmali, J. Laubova, J. Sikulova, M. A. Preston, R. Khakhria, H. Karch, H. Klazarova, and O. Nyc. 1997. Human Escherichia coli $\mathrm{O} 157: \mathrm{H} 7$ infection associated with the consumption of unpasteurized goat's milk. Epidemiol. Infect. 119:299-305.

Blanco, M., J. E. Blanco, A. Mora, J. Rey, J. M. Alonso, M. Hermoso, J. Hermoso, M. P. Alonso, G. Dahbi, E. A. Gonzalez, M. I. Bernardez, and J. Blanco. 2003. Serotypes, virulence genes and intimin types of Shiga toxin-producing Escherichia coli isolated from healthy sheep in Spain. J. Clin. Microbiol. 41:1351-1356.

Boerlin, P., S. A. McEwen, F. Boerlin-Petzold, J. B. Wilson, R. P. Johnson, and C. L. Gyles. 1999. Associations between virulence factors of Shiga toxin-producing Escherichia coli and disease in humans. J. Clin. Microbiol. 37:497-503.

Burnens, A. P., A. Frey, H. Lior, and J. Nicolet. 1995. Prevalence and clinical significance of verocytotoxin-producing Escherichia coli (VTEC) isolated from cattle in herds with and without calf diarrhoea. J. Vet. Med. B 42:311-318.

Chiodini, R. J., and J. Hermon-Taylor. 1993. The thermal resistance of Mycobacterium paratuberculosis in raw milk under conditions simulating pasteurization. J. Vet. Diagn. Invest. 5:629-631.

Cody, S. H., S. L. Abbott, A. A. Marfin, B. Schulz, P. Wagner, K. Robbins, J. C. Mohle-Boetani, and D. J. Vugia. 1999. Two outbreaks of multidrug-resistant Salmonella serotype Typhimurium DT104 infections linked to raw-milk cheese in Northern California. J. Am. Med. Assoc. 281:1805-1810.

Corti, S., and R. Stephan. 2002. Detection of Mycobacterium avium subspecies paratuberculosis specific IS900 insertion sequences in bulk-tank milk samples obtained from different regions throughout Switzerland. BMC Microbiol. 26:15.

Cousins, D. V., R. Whittington, I. Marsh, A. Masters, R. J. Evans, and P. Kluver. 1999. Mycobacteria distinct from Mycobacterium avium subsp. paratuberculosis isolated from the faeces of ruminants possess IS900-like sequences detectable by IS900 polymerase chain reaction: Implications for diagnosis. Mol. Cell. Prob. 14:431-442. 
De Buyser, M. L., B. Dufour, M. Maire, and V. Lafarge. 2001. Implication of milk and milk products in food-borne diseases in France and in different industrialised countries. Int. J. Food Microbiol. 67:1-17.

De Valk, H., E. Delarocque-Astagneaue, G. Colomb, S. Ple, E. Godard, V. Vaillant, S. Haeghebaert, P. H. Bouvet, F. Grimont, P. Grimot, and J. C. Desenclos. 2000. A community-wide outbreak of Salmonella enterica serotype Typhimurium infection associated with eating a raw milk soft cheese in France. Epidemiol. Infect. 124:1-7.

Djonne, B., M. R. Jensen, I. R. Grant, and G. Holstad. 2003. Detection by immunomagnetic PCR of Mycobacterium avium subsp. paratuberculosis in milk from dairy goats in Norway. Vet. Microbiol. 92:135-143.

Englund, S., G. Bölske, and K. E. Johansson. 2002. An IS900-like sequence found in a Mycobacterium sp. other than Mycobacterium avium subsp. paratuberculosis. FEMS Microbiol. Lett. 209:267-271.

Foschino, R., A. Invernizzi, R. Barucco, and K. Stradiotto. 2002. Microbial composition, including the incidence of pathogens, of goat milk from the bergamo region of Italy during a lactation year. J. Dairy Res. 69:213-225.

Grant, I. R., H. J. Ball, and M. T. Rowe. 1998. Effect of high-temperature, short-time (HTST) pasteurization on milk containing low numbers of Mycobacterium paratuberculosis. Lett. Appl. Microbiol. 26:166-170.

Grant, I. R., E. I. Hitchings, A. McCarteny, F. Ferguson, and M. T. Rowe. 2002. Effect of commercial-scale high-temperature, shorttime pasteurization on the viability of Mycobacterium paratuberculosis in naturally infected cows' milk. Appl. Environ. Microbiol. 68:602-607.

Grant I. R., L. M. O'Riordan, H. J. Ball, and M. T. Rowe. 2001. Incidence of Mycobacterium paratuberculosis in raw sheep and goats' milk in England, Wales and Northern Ireland. Vet. Microbiol. 79:123-131.

Guinée, P. A., W. H. Jansen, T. Wadström, and R. Sellwood. 1981. Escherichia coli associated with neonatal diarrhoea in piglets and calves. Curr. Top. Vet. Anim. Sci. 13:126-162.

Harrington, P., J. Archer, J. P. Davis, D. R. Croft, J. K. Varma, and EIC officers. 2002. Outbreak of Campylobacter jejuni infections associated with drinking unpasteurized milk procured through a cow-leasing program-Wisconsin, 2001. MMWR 51:548-549.

Hermon-Taylor, J., T. J. Bull, J. M. Sheridan, J. Cheng, M. L. Stellakis, and N. Sumar. 2000. Causation of Crohn's disease by Mycobacterium avium subspecies paratuberculosis. Can. J. Gastroenterol. 14:521-539.

Hutchinson, D. N., F. J. Bolton, W. C. Jelley, W. G. Mathews, D. R. Telford, D. E. Counter, E. G. Jessop, and S. D. Horsley. 1985. Campylobacter enteritis associated with consumption of raw goat's milk. Lancet 1:1037-1038.

Kalman, M., E. Szollosi, B. Czermann, M. Zimanyi, S. Szekeres, and M. Kalman. 2000. Milkborne campylobacter infection in Hungary. J. Food Prot. 63:1426-1429.

Keene, W. E., K. Hedberg, D. E. Herriott, D. D. Hancock, R. W. McKay, T. J. Barrett, and D. W. Fleming. 1997. A prolonged outbreak of Escherichia coli O157:H7 infections caused by commercially distributed raw milk. J. Infect. Dis. 176:815-818.

Keswani, J., and J. F. Frank. 1998. Thermal inactivation of Mycobacterium paratuberculosis in milk. J. Food Prot. 61:974-978.
Little, C. L., and J. De Louvois. 1999. Health risks associated with unpasteurized goats' and ewes' milk on retail sale in England and Wales. A PHLS Dairy Products Working Group Study. Epidemiol. Infect. 122:403-408.

Martin, M. L., L. D. Shipman, J. G. Wells, M. E. Potter, K. Hedberg, I. K. Wachsmuth, R. V. Tauxe, J. P. Davies, J. Arnoldi, and J. Tilleli. 1986. Isolation of Escherichia coli O157:H7 from dairy cattle associated with two cases of hemolytic uremic syndrome. Lancet ll:1043.

McIntyre, L., J. Fung, A. Paccagnella, J. Isaac-Renton, F. Rockwell, B. Emerson, and T. Preston. 2002. Escherichia coli 0157 outbreak associated with the ingestion of unpasteurized goat's milk in British Columbia, 2001. Can. Commun. Dis. Rep. 28:6-8.

Morgan, R., T. Massouras, M. Barbosa, L. Roseiro, F. Ravasco, I. Kandarakis, V. Bonnin, M. Fistakoris, E. Anifantakis, G. Jaubert, and D. Raynal-Ljutovac. 2003. Characteristics of goat milk collected from small and medium enterprises in Greece, Portugal and France. Small Rumin. Res. 47:39-49.

Pearce, L. E., H. Tuan Truong, R. A. Crawford, G. F. Yates, S. Cavaignac, and G. W. de Lisle. 2001. Effect of turbulent-flow pasteurisation on survival of Mycobacterium avium subsp. paratuberculosis added to raw milk. Appl. Environ. Microbiol. 67:3964-3969.

Piérard, D., G. Muyldermans, L. Moriau, D. Stevens, and S. Lauwers. 1998. Identification of new Verocytotoxin type 2 variant B-subunit genes in human and animal Escherichia coli isolates. J. Clin. Microbiol. 36:3317-3322.

Riley, L. W., R. S. Remis, S. D. Helgerson, H. B. McGee, J. G. Wells, B. R. Davis, R. J. Herbert, E. S. Olcott, L. M. Johnson, N. T. Hargrett, P. A. Blake, and M. L. Cohen. 1983. Hemorrhagic colitis associated with a rare Escherichia coli serotype. N. Engl. J. Med. 308:681-685.

Roberts, D. 1985. Microbiological aspects of goat's milk. A public health laboratory service survey. J. Hyg. 94:31-44.

Schmidt, H., L. Beutin, and H. Karch. 1995. Molecular analysis of the plasmid encoded hemolysin of Escherichia coli O157:H7 strain EDL 933. Infect. Immunol. 63:1055-1061.

Schmidt, H., H. Rüssmann, A. Schwarzkopf, S. Aleksic, J. Heesemann, and H. Karch. 1994. Prevalence of attaching and effacing Escherichia coli in stool samples from patients and controls. Zentbl. Bakteriol. 281:201-213.

Stephan, R., and K. Bühler. 2001. A survey of the prevalence of $E$. coli $\mathrm{O} 157$ and other Shigatoxin-producing $E$. coli in bulk-tank milk samples from north-east Switzerland. Arch. Lebensmittelhyg. 52:122-123.

Stephan, R., K. Bühler, and C. Lutz. 2002. Prevalence of genes encoding enterotoxins, exfoliative toxins and toxic shock syndrome toxin 1 in $S$. aureus strains isolated from bulk-tank milk samples in Switzerland. Milchwissenschaft 57:502-504.

Streeter, R. N., G. F. Hoffsis, S. Bech-Nielsen, W. P. Shulaw, and D. M. Rings. 1995. Isolation of Mycobacterium paratuberculosis from colostrum and milk of subclinically infected cows. Am. J. Vet. Res. 56:1322-1324.

Sung, N., and M. T. Collins. 1998. Thermal tolerance of Mycobacterium paratuberculosis. Appl. Environ. Microbiol. 64:999-1005.

Yamamoto, T., and M. Nakazawa. 1997. Detection and sequences of the enteroaggregative Escherichia coli heat-stable enterotoxin 1 gene in enterotoxigenic $E$. coli strains isolated from piglets and calves with diarrhea. J. Clin. Microbiol. 35:223-227. 